\title{
Clinical pharmacology of tyrosine kinase inhibitors becoming generic drugs: the regulatory perspective
}

\author{
Niels Eckstein", Lea Röper, Bodo Haas, Henrike Potthast, Ulrike Hermes, Christoph Unkrig, Frauke Naumann-Winter \\ and Harald Enzmann
}

\begin{abstract}
Over the last decades, billions have been spent and huge efforts have been taken in basic and clinical cancer research [CA Cancer J Clin 63:11-30]. About a decade ago, the arms race between drugs and cancer cells reached a new level by introduction of tyrosine kinase inhibitors (TKI) into pharmacological anti-cancer therapy. According to their molecular mechanism of action, TKI in contrast to so-called "classic" or "conventional" cytostatics belong to the group of targeted cancer medicines, characterized by accurately fitting with biological structures (i.e. active centers of kinases). Numerous (partly orphan) indications are covered by this new class of substances. Approximately ten years after the first substances of this class of medicines were authorized, patent protection will end within the next years. The following article covers clinical meaning and regulatory status of anti-cancer TKI and gives an outlook to what is expected from the introduction of generic anti-cancer TKI.
\end{abstract}

Keywords: Narrow therapeutic index drugs (NTID), Tyrosine kinase inhibitors (TKI), Orphan drug status

\section{Introduction}

Pharmacological cancer therapy for decades was performed with non-targeted mostly DNA-interacting cytostatic drugs. Administration of these so-called conventional cytostatics usually is entailed with severe side-effects [1]. One of the main disadvantages of those substances is that they do not specifically target cancer cells but all (also benign) rapidly dividing cells. This non-specific mechanism of action was the rationale to develop specifically targeted anti-cancer TKI. Initially, great expectations were associated with these drugs; some were met, others not. Tyrosine kinase inhibitors (TKI) are a very worthy additional option for physicians in clinical management of certain types and lines of cancer treatment (refer to Table 1 for a tabular overview). However, the initial expectation of a new era of cancer-therapy with substantially less side effects was not fulfilled. TKI have numerous, partly severe side effects eventually entailed with fatal outcome (Table 2). On the other hand, when a tumor becomes resistant to

\footnotetext{
* Correspondence: niels.eckstein@bfarm.de

Federal Institute of Drugs and Medical Devices, Kurt-Georg-Kiesinger-Allee 3, Bonn 53175, Germany
}

conventional or targeted anti-cancer therapy, TKI serve as additional options in second-, third- and/or fourth-line therapy regimes according to their approved indications. For instance Sunitinib is approved after Imatinib resistance formation in gastrointestinal stromal tumors (GIST), and Lapatinib after non-responding to antracycline- or taxane-based chemotherapy in combination with Trastuzumab in HER-2 positive breast cancer. Taken together, TKI are a valuable extension of the cancer drug armamentarium $[2,3]$.

\section{Molecular mechanism of action}

Many chemotherapy-naive and nearly all drug resistant tumors are characterized by pronounced ReceptorTyrosine-Kinase (RTK) signaling. This pattern is at least in part due to the fact that chemoresistance can be triggered by overexpression and/or activation of RTKs: ERB B1-4, IGF-1R, VEGFR 1-3, and PDGF-receptor family members $[4,5]$. The underlying mechanisms of this overactivation are diverse and comprise at least the following mechanisms [6]. 
Table 1 General information on anti-cancer TKI

\begin{tabular}{|c|c|c|c|c|c|c|c|}
\hline $\begin{array}{l}\text { Tyrosine kinase } \\
\text { inhibitor (INN) }\end{array}$ & $\begin{array}{l}\text { Branded } \\
\text { name }\end{array}$ & $\begin{array}{l}\text { Market Authorization } \\
\text { Holder (MAH) }\end{array}$ & $\begin{array}{l}\text { Target tyrosine } \\
\text { kinases }\end{array}$ & Indication(s) & $\begin{array}{l}\text { European } \\
\text { birth date }\end{array}$ & CMA & Orphan designation \\
\hline Bosutinib & Bosulifø & Pfizer & BCR-ABL,SRC & $\begin{array}{l}\text { Patients with CML for which Imatinib, } \\
\text { Nilotinib, and Dasatinib are not } \\
\text { appropriate }\end{array}$ & $27^{\text {th }}$ March 2013 & Yes & CML \\
\hline Dasatinib & Sprycel ${ }^{\circledast}$ & Bristol-Myers Squibb & BCR-ABL & CML & $23^{\text {th }}$ December 2005 & No & $\mathrm{CML}, \mathrm{ALL}$ \\
\hline Erlotinib & Tarceva $^{\oplus}$ & Hoffman-La Roche & EGFR & NSCLC, pancreatic cancer & $19^{\text {th }}$ September 2005 & No & No \\
\hline Gefitinib & |ressa ${ }^{\oplus}$ & Astra Zeneca & EGFR & $\begin{array}{l}\text { NSCLC in carriers of activating } \\
\text { EGFR-mutations }\end{array}$ & $24^{\text {th }}$ June 2010 & No & No \\
\hline Imatinib & Glivec $^{\oplus}$ & Novartis & $\begin{array}{l}\text { BCR-ABL, KIT, PDGFR-A, } \\
\text { PDGFR-B }\end{array}$ & $\begin{array}{l}\text { CML, GIST, BCR-ABL- positive ALL, } \\
\text { dermatofibrosarcoma protuberans, } \\
\text { myeloproliferative neoplasms, } \\
\text { hypereosinophilic syndromes }\end{array}$ & $7^{\text {th }}$ of November 2001 & No & Expired and withdrawn \\
\hline Lapatinib & Tyverb ${ }^{\oplus}$ & Glaxo Smith Kline & ERBB2 (HER-2) & HER-2 positive breast cancer & $10^{\text {th }}$ June 2008 & Yes & No \\
\hline Nilotinib ${ }^{1}$ & Tasigna ${ }^{\oplus}$ & Novartis & $\begin{array}{l}\text { BCR-ABL, KIT,PDGFR-A, } \\
\text { PDGFR-B }\end{array}$ & CML & $19^{\text {th }}$ November 2007 & No & $\mathrm{CML}$ \\
\hline Pazopanib & Votrient $^{\oplus}$ & Glaxo Smith Kline & VEGFR, PDGFR, KIT & Renal cell carcinoma, STS & $14^{\text {th }}$ June 2010 & No & Withdrawn \\
\hline Ponatinib ${ }^{2}$ & |clusig ${ }^{\oplus}$ & Ariad & BCR-ABL & $\begin{array}{l}\text { Patients with CML for which Imatinib, } \\
\text { Nilotinib, and Dasatinib are not } \\
\text { appropriate (or patients carrying a } \\
\text { T315I single-point-mutation) }\end{array}$ & $1^{\text {st }}$ July 2013 & & $C M L, A L L$ \\
\hline Sorafenib & Nexavar ${ }^{\oplus}$ & Bayer & VEGFR-2,VEGFR-3 & $\begin{array}{l}\text { Renal cell carcinoma, hepatocellular } \\
\text { carcinoma }\end{array}$ & $19^{\text {th }}$ July 2006 & No & $\begin{array}{l}\text { Renal cell carcinoma, } \\
\text { Hepatocellular carcinoma }\end{array}$ \\
\hline Sunitinib & Sutent ${ }^{\oplus}$ & Pfizer & $\begin{array}{l}\text { VEGFR 1-3, PDGFR-A, } \\
\text { PDGFR-B; KIT, FLT3 }\end{array}$ & Renal cell carcinoma, GIST, pNET & $19^{\text {th }}$ July 2006 & $\begin{array}{l}\text { Initially, then full } \\
\text { approval }\end{array}$ & Withdrawn \\
\hline
\end{tabular}

ALL, acute lymphatic leukemia; CML, chronic myeloid leukemia ; CMA, Conditional Marketing Authorization (none of the above mentioned is currently authorized under exceptional circumstances, according to European Medicines Agency (EMA) website accessed in Sept 2013 [15]); GIST, gastrointestinal stromal tumor; MA, Marketing Authorization; MAH, Marketing Authorization Holder; NSCLC, non-small cell lung cancer; European Medicines Agency (EMA) website accessed in Sept 2013 [15]); GIST, gastrointestinal stromal tumor; MA, Marketing Authorization; MAH, Marketing Authorization Holder; NSCLC, non-Small cell lung cancer;
pNET, pancreatic neuroendocrine tumors; STS, soft tissue sarcoma; 'Nilotinib is similar to Imatinib according to the orphan regulation; ${ }^{2}$ US-Food and Drug Administration (FDA) asked the manufacturer of Ponatinib to suspend marketing due to the risk of life-threatening blood clots and severe narrowing of blood vessels; source of information: European Public Assessment Reports (EPARs) of the above mentioned TKI [15]. 
Table 2 Safety profiles of TKI

\begin{tabular}{|c|c|c|c|c|c|c|c|}
\hline $\begin{array}{l}\text { Small } \\
\text { molecule TKI }\end{array}$ & CNS & $\begin{array}{l}\text { Nerve } \\
\text { disorders }\end{array}$ & Eye disorders & Heart disorders & $\begin{array}{l}\text { Lung airways } \\
\text { disorders }\end{array}$ & $\begin{array}{l}\text { Thyroid } \\
\text { disorders }\end{array}$ & $\begin{array}{l}\text { Liver, Bile } \\
\text { disorders }\end{array}$ \\
\hline Bosutinib & & $X X$ & & $X X$ & $X X$ & & $X X$ \\
\hline Dasatinib & $x$ & $X X$ & $X X$ & $X X$ & $X X$ & & $x$ \\
\hline Erlotinib & $x$ & $X X$ & $X X$ & & $X X$ & & $x$ \\
\hline Gefitinib & & & $X X$ & & $X X$ & & $X X$ \\
\hline Imatinib & $x$ & $X X$ & $X X$ & $x$ & $X X$ & $x$ & $X X$ \\
\hline Lapatinib & $x$ & $X X$ & & $x$ & $X X$ & & $X X$ \\
\hline Nilotinib & $x$ & $X X$ & $X X$ & $X X$ & $X X$ & & $X X$ \\
\hline Pazopanib & & $X X$ & $X X$ & $x$ & $X X$ & $X X$ & $X X$ \\
\hline Ponatinib & & $X X$ & $X X$ & $X X$ & $X X$ & & $X X$ \\
\hline Sorafenib & $x$ & $X X$ & & $x$ & $x$ & & $x$ \\
\hline Sunitinib & $x$ & $X X$ & $X X$ & $x$ & $X X$ & $X X$ & $x$ \\
\hline $\begin{array}{l}\text { Small } \\
\text { molecule TKI }\end{array}$ & $\begin{array}{l}\text { Gastrointestinal } \\
\text { disorders }\end{array}$ & $\begin{array}{l}\text { Renal } \\
\text { disorders }\end{array}$ & $\begin{array}{l}\text { Musculoskeletal and } \\
\text { bone disorders }\end{array}$ & $\begin{array}{l}\text { Blood and } \\
\text { lymphatic system }\end{array}$ & $\begin{array}{l}\text { Vascular } \\
\text { disorders }\end{array}$ & $\begin{array}{l}\text { Skin } \\
\text { disorders }\end{array}$ & CMR \\
\hline Bosutinib & $X X$ & $X X$ & $X X$ & $X X$ & & $X X$ & \\
\hline Dasatinib & $X X$ & $x$ & $x$ & $X X$ & $X X$ & $X X$ & $X X$ \\
\hline Erlotinib & $X X$ & $X X$ & & $x$ & & $x X$ & $X X$ \\
\hline Gefitinib & $X X$ & $X X$ & & & $X X$ & $X X$ & $X X$ \\
\hline Imatinib & $X X$ & $x$ & $X X$ & $X X$ & $x$ & $X X$ & $X X$ \\
\hline Lapatinib & $X X$ & & $X X$ & & $X X$ & $X X$ & $X X$ \\
\hline Nilotinib & $x$ & $x$ & $x$ & $X X$ & $x$ & $X X$ & $X X$ \\
\hline Pazopanib & $X X$ & $X X$ & $X X$ & $X X$ & $X X$ & $X X$ & $X X$ \\
\hline Ponatinib & $X X$ & & $X X$ & $X X$ & $X X$ & $x X$ & \\
\hline Sorafenib & $x$ & $x$ & $x$ & $X X$ & $X X$ & $X X$ & $X X$ \\
\hline Sunitinib & $X X$ & $X X$ & $X X$ & $X X$ & $X X$ & $X X$ & $X X$ \\
\hline
\end{tabular}

$\mathrm{XX}=$ common, very common; $\mathrm{X}=$ rare, uncommon; $\mathrm{CMR}$, carcinogenic, mutagenic and toxic for reproductive system; CNS, central nervous system; source of information: Summaries of Product Characteristics (SmPCs) of marketed TKI [16].

$\rightarrow$ Formation of a self-sustaining autocrine loop with secreted growth factors such as EGF, VEGF, PDGF, amphiregulin or others [5].

$\rightarrow$ Expression of intrinsically active RTK in the cell membrane [7].

$\rightarrow$ Over-activation of downstream signaling by imbalance of tumor-suppressor genes (p53, PTEN) and (proto-) oncogenes (PI3K, monomeric G Proteins such as RAS, RAF and others) [8] etc.

In vitro investigations of cancer cell-lines derived from numerous tumor-entities regularly uncovered receptor tyrosine kinase (i.e. EGFR) activation by phosphorylation of specific residues located in the $\beta$-subunit $[9,10]$. Downstream the adaptor protein GAB1 (Grb2-associated binder 1) recruits PI3 kinase to phosphorylated EGFR [11]. The main function of GAB1 is to enhance PI3K/AKT activation thereby prolonging MAPK signaling [12]. While RAS/RAF/MEK/ERK signaling cascade usually ends up in cellular proliferation and tumorigenic transformation, enhanced AKT-kinase signaling usually is entailed with evasion of apoptosis, which is the turning-point in drug resistance formation [13]. Given this, TKI can interrupt signaling cascades evading apoptosis, thereby re-sensitizing cancer cells to induction of apoptosis. Figure 1 gives a schematic overview of the molecular mechanisms of action of TKI.

\section{Challenges of generic TKI drugs in cancer therapy}

According to their European Birth Date during the past decade, these substances successively will be running off-patent within the next years (Table 1). From a regulatory point of view, this raises the question how marketing authorization applications (MAA) should be filed and especially, how therapeutic equivalence should be established for generic applications. In general, demonstrated bioequivalence (BE) allows generic medicinal products to refer to the efficacy and safety data of the originator medicinal product. It is easy to anticipate, that numerous questions in this regard will arise in the near future. 


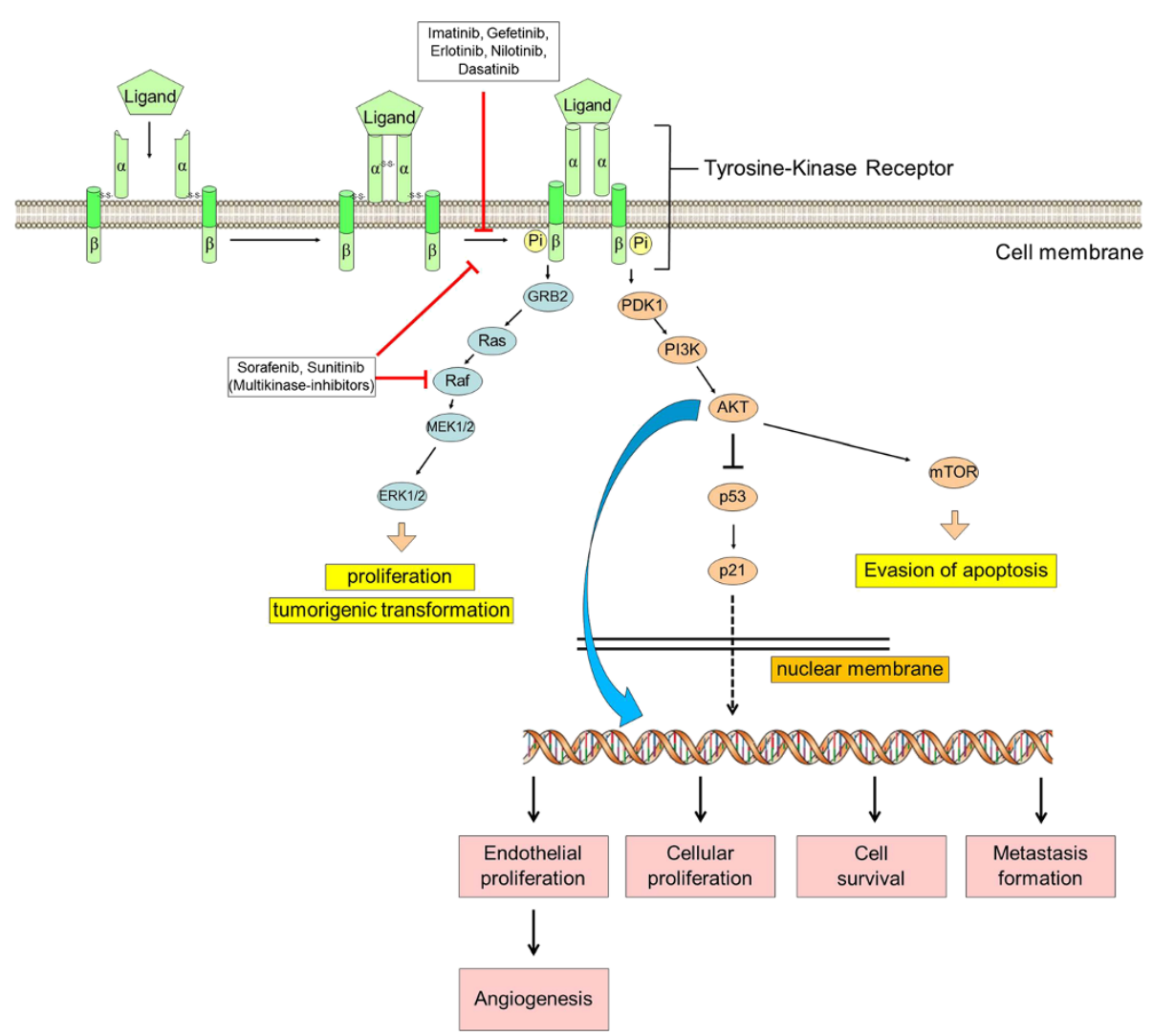

Figure 1 Schematic model of tumorigenic signaling pathways and their inhibition by anti-cancer-TKI.

Aqueous (non-complicated) intravenously applied drug products have a $100 \%$ bioavailability directly per definition, thus, no BE studies are required for a MAA of such generic drugs. However, for orally applied drug products, $\mathrm{BE}$ with the originator product needs to be shown, which may be done using patients or healthy volunteers in respective in vivo studies or by means of comparative invitro investigations.

Since decades BE-acceptance criteria for AUC and $\mathrm{C}_{\max }$ require the $90 \%$ confidence intervals being completely within $80-125 \%$ (for AUC and $C_{\max }$ ) to assume $\mathrm{BE}$. The acceptance range may be tightened to 90 $111 \%$ for one or both pharmacokinetic characteristics according to the European BE-Guideline [14] in the case of narrow therapeutic index drugs (NTID). In cases of class I and III compounds having identified not to have a narrow therapeutic index - specific in-vitro dissolution data may substitute for human BE-studies considering also particular requirements on excipients. This concept follows the principles of the biopharmaceutical classification system (BCS) [14].

It is likely that numerous questions in regard to the appropriate data package will arise in the near future including questions on the appropriate study design, on the appropriate study population, nutrition status, single or repeated dose-design, appropriate BCS classification of the individual compound or the classification as NTID.

MAA for new generics may be processed via different regulatory authorizations routes, i.e. national procedures in European member states, decentralized procedures involving several European member states or centralized procedures for all European member states. As the latter is an option only for generics for which the originator medicinal products already obtained marketing authorization from a centralized procedure, this option may receive more attention with the increasing number of medicinal products with centralized authorizations that are running off data protection and patent in the next years.

With the intent to enable a consistent approach for these different routes the European Medicines Agency (EMA) issued an initiative to harmonize the data requirements throughout European Member States, i.e. EMA initiated a pro-active program "Product-specific Bioequivalence-Guidance for Generics" [15]. EMA defines the objective of this initiative as follows: "Product specific guidance for the bioequivalence assessment of immediate release generic formulations should a priori be defined." Thus, applicants should be given a clear scientific guidance, how to design BE-studies and, thus, how to file generic applications. This program includes 
BCS-classifications for drug substances, so that a harmonized view on the BCS classification and consequently the appropriateness of a BCS-based biowaiver approach can be expected for respective products. Furthermore, the guidance provides information on the type of expected data, e.g. appropriate study population (patients or healthy volunteers), mode of administration (fasten or fed), single dose or steady state-design, appropriate dose strength and analytes, the classification as NTID. The first wave of 16 medicinal products is dominated by anti-infectives and TKI. Dasatinib, Erlotinib, Imatinib, Sorafenib and Sunitinib are covered in this first round of harmonization [15].

From a clinician's point of view regarding drug safety (Table 2), one could be tempted to assume that all anticancer medicinal products including TKI are considered as NTID. However, this is not the case. Different definitions of NTID by different regulatory agencies do exist. US-FDA classification of narrow therapeutic ratio:

$\rightarrow$ Less than a 2-fold difference in median lethal dose $\left(\mathrm{LD}_{50}\right)$ and median effective dose values $\left(\mathrm{ED}_{50}\right)$, -or

$\rightarrow$ Less than 2-fold difference in the minimum toxic concentrations (MTC) and minimum effective concentrations (MEC) in the blood or

$\rightarrow$ Safe and effective use of the drug products require careful titration and patient monitoring.

In contrast to the US, for the EU no list of substances with NTID-designation is available. So far the consideration of a given substance as NTID is mainly based on national traditions. Only for a few medicinal substances (e.g. Ciclosporine, Tacrolimus) a harmonized EU decision was issued by a referral procedure. According to the draft "Product-specific Bioequivalence - Guidance for Generics" no drug is newly considered as NTID, only Tacrolimus is considered as such based on the previously finalized referral procedure.

According to the European BE-Guideline [14] clinical considerations are the basis for NTID decisions. Thus, safety-and efficacy profile have to be taken into account.

Most conventional cytotoxic medicinal products are given parenterally for a short duration in repeated cycles. They are mostly dosed on an individual basis (e.g. body surface or weight). The recommended dose is normally the maximum tolerated dose (MTD) or close to it.

Marketed TKI drugs are typically given continuously via the oral route and at a flat dose. Although a most effective and durable target saturation is the primary objective for dose development of TKI drugs, it is obvious that for several TKI drugs the recommended dose is the same as the reported MTD, e.g. Bosutinib, Pazopanib, Ponatinib or Sunitinib (Table 3). The dose-limiting toxicities include grade 3 gastrointestinal and hepatic toxicities, grade 3 skin toxicities, grade 3 fatigue, and grade 3 hypertension. For Sunitinib grade 2 bullous skin toxicity, grade 3 fatigue, and grade 3 hypertension are reported as doselimiting toxicities. Furthermore, at approx. twice the therapeutic concentration a grade 2 QT-prolongation is expected (Summary of Product Characteristics/SmPC Sutent $\left.{ }^{\circ}[16]\right)$.

From a clinical point of view there are arguments for consideration as an NTID for selective TKI which are elucidated for the example of Sunitinib: The dose of $50 \mathrm{mg} / \mathrm{d}$ is the recommended dose for renal cell carcinoma and the MTD at the same time. The documented adverse events (AE) and adverse drug reactions (ADR) are serious, and toxicity may be difficult to control due to long half-life of parent compound and main metabolite (40-60 $\mathrm{h}$ and 80-110 h, respectively). The described toxicity induces a high probability of dose reductions with the intent to reduce exposure. The patient safety may be impaired in case of an exchange between originator and generic medicinal product following dose reduction: Dose reductions of $12.5 \mathrm{mg}$ represent a $25 \%$ and $33 \%$ decrease from the recommended dose for renal cell carcinoma and neuroendocrine tumors of pancreatic origin, respectively. In case of exchange of the originator for a generic drug the AUC from the reduced dose of the generic may be the same as the AUC from the normal dose of the originator if normal acceptance criteria for BE (90\% CI for AUC and $\mathrm{C}_{\max } 80-125 \%$ ) are applied.

From a safety point of view it should be mentioned that chronic exposure to a dose that was identified as the maximum tolerable dose in a short term study may render the tolerable short term toxicity into intolerable long term toxicity.

\section{Safety of certain TKI}

Dasatinib, Nilotinib \& Bosutinib - CML-TKI with different safety profiles from a regulatory point of view and availability of second generation TKI

In general TKI are well tolerated in clinical practice, particularly, if compared with the toxicity of cytostatic drugs normally used in oncology. Often side-effects are only mild (grade 2 and lower) and occur early in the treatment course. Frequently they last only some days or weeks and resolve spontaneously. Moreover, even if drug-related toxicity requires drug discontinuation, reexposition is often successful and permanent dose reduction is rarely necessary.

The advent of Imatinib in 2001 has dramatically changed the prognosis in patients with chronic myeloid leukemia (CML): The five year survival rate of patients with chronic phase CML improved from approximately $20 \%$ in the pre-TKI era to more than $90 \%$ patients [17]. In those patients who achieve a stable cytogenetic response with Imatinib overall survival is reported with 
Table 3 Clinical pharmakokinetic profiles of TKI marketed in the EU

\begin{tabular}{|c|c|c|c|c|c|c|c|c|c|c|}
\hline TKI & $t_{\max }(h)$ & $\begin{array}{l}\text { Bioavailability } \\
\text { (oral, \%) }\end{array}$ & $\begin{array}{l}\text { Concomitant } \\
\text { food intake } \\
\text { effect on } \\
\text { bioavailability }\end{array}$ & $\begin{array}{l}\text { Concomitant } \\
\text { food intake: FDA } \\
\text { recommendation }\end{array}$ & $\begin{array}{l}\mathrm{V}(\mathrm{L} / \mathrm{kg}) \\
70-\mathrm{kg} \text { subject } \\
\text { assumed }\end{array}$ & $\begin{array}{l}\text { Primary } \\
\text { enzymes } \\
\text { involved in } \\
\text { metabolism }\end{array}$ & $\begin{array}{l}\text { Major } \\
\text { metabolites }\end{array}$ & $\begin{array}{l}\text { Plasma } \\
\text { half-life (h) }\end{array}$ & $\begin{array}{l}\text { Plasma } \\
\text { protein } \\
\text { binding (\%) }\end{array}$ & $\begin{array}{l}\text { Suggested } \\
\text { threshold for } \\
\text { response or } \\
\text { concentration } \\
\text { attained in } \\
\text { therapy (mg/L) }\end{array}$ \\
\hline Bosutinib & 6 & $\begin{array}{l}18 \text { [20] derived } \\
\text { from colon } \\
\text { tumor } \\
\text { xenograft } \\
\text { models }\end{array}$ & & With food & $131-214$ [21] & CYP3A4 & $\begin{array}{l}\text { M2 } \\
\text { (oxydechlorinated } \\
\text { Bosutinib) M5 } \\
\text { (N-desmethyl } \\
\text { Bosutinib) }\end{array}$ & & $94-96$ & \\
\hline Dasatinib & $0.5-3$ & $<34$ & $\begin{array}{l}\text { Increases } \\
\text { AUC (14\%) }\end{array}$ & $\begin{array}{l}\text { With/without } \\
\text { food }\end{array}$ & $30-40$ & CYP3A4, FMO-3 & $\begin{array}{l}\text { M4 (BMS-582691), } \\
\text { M5 (BMS-606181), } \\
\text { M6 (BMS-573188) }\end{array}$ & $3-5$ & $92-97$ & $0.01-0.1[22]$ \\
\hline Erlotinib & 4 & $69-76$ & $\begin{array}{l}\text { Increases } \\
\text { bioavailability } \\
(24 \%-31 \%)\end{array}$ & Without food & 3 & $\begin{array}{l}\text { CYP3A4, CYP3A5, } \\
\text { CYP1A2 }\end{array}$ & $\begin{array}{l}\text { NorErlotinib } \\
\text { (OSI-420) }\end{array}$ & 41 & $92-95$ & $>0.5$ \\
\hline Gefitinib & $3-7$ & 57 & No effect & $\begin{array}{l}\text { With/without } \\
\text { food }\end{array}$ & 24 & $\begin{array}{l}\text { CYP3A4, CYP2D6, } \\
\text { CYP3A5 (possibly } \\
\text { CYP1A1) }\end{array}$ & $\begin{array}{l}\text { NorGefitinib } \\
\text { (M523595) }\end{array}$ & 48 & 79 & $>0.2$ \\
\hline Imatinib & $2-4$ & 98 & No effect & With food & $\begin{array}{l}\text { 2-6 (Imatinib), } \\
15-40 \\
\text { (Norlmatinib) }\end{array}$ & $\begin{array}{l}\text { CYP3A4, CYP3A5, } \\
\text { CYP2C8 }\end{array}$ & $\begin{array}{l}\text { Norlmatinib } \\
\text { (CGP74588) }\end{array}$ & $\begin{array}{l}\text { 12-20 } \\
\text { (Imatinib), } \\
40-74 \\
\text { (Norlmatinib) }\end{array}$ & $\begin{array}{l}95 \text { (Imatinib } \\
\text { and } \\
\text { Norlmatinib) }\end{array}$ & $\begin{array}{l}>1(\mathrm{CML} \\
\text { and GIST) }\end{array}$ \\
\hline Lapatinib & $3-5$ & - & $\begin{array}{l}\text { Increases AUC } \\
(167 \%-325 \%)\end{array}$ & Without food & 31 & CYP3A4, CYP3A5 & $\begin{array}{l}\text { Norlapatinib } \\
\text { (GW690006) }\end{array}$ & 14 & $>99$ & $\begin{array}{l}>0.5 \text { mean } \\
\text { concentration } \\
\text { in patients } \\
\text { prescribed } \\
1500 \mathrm{mg} \text { once } \\
\text { daily [23] }\end{array}$ \\
\hline Nilotinib & 3 & 30 & $\begin{array}{l}\text { Increases } \\
C_{\max }(112 \%) \\
\text { and AUC } \\
(82 \%)\end{array}$ & Without food & $10-15$ & CYP3A4, CYP2C8 & - & $15-17$ & 98 & $\begin{array}{l}>0.6 C_{\min } \\
\text { concentration } \\
\text { applicable to } \\
\text { quartile } 1 \text { from } \\
\text { cytogenetic } \\
\text { response [24] }\end{array}$ \\
\hline Pazopanib & 2.8 & $14-39$ & $\begin{array}{l}\text { Increases AUC } \\
\text { and } C_{\max }(2 \text {-fold })\end{array}$ & Without food & $0.1-0.2$ & $\begin{array}{l}\text { CYP3A4, CYP1A2, } \\
\text { CYP2C8 }\end{array}$ & $\begin{array}{l}\text { Pazopanib M24, } \\
\text { Pazopanib M26, } \\
\text { Pazopanib M27 }\end{array}$ & 31 & $>99$ & $>20$ \\
\hline Ponatinib & & & & $\begin{array}{l}\text { With/without } \\
\text { food }\end{array}$ & & CYP3A4 (MRI PI) & $\begin{array}{l}\text { inactive carboxylic } \\
\text { acid }\end{array}$ & & $>99$ & \\
\hline Sorafenib & $2-14$ & $<50$ & $\begin{array}{l}\text { Reduces } \\
\text { bioavailability } \\
(29 \%)\end{array}$ & Without food & $3-6$ & CYP3A4, UGT1A9 & $\begin{array}{l}\text { Norsorafenib, } \\
\text { Sorafenib N-oxide } \\
\text { (BAY } 67 \text { 3472) }\end{array}$ & $20-40$ & $>99$ & $>3$ \\
\hline Sunitinib & $6-12$ & - & No effect & $\begin{array}{l}\text { With/without } \\
\text { food }\end{array}$ & 30 & CYP3A4 & $\begin{array}{l}\text { Norsunitinib } \\
\text { (SU12662) }\end{array}$ & $\begin{array}{l}40-60 \\
\text { (Sunitinib), } \\
80-110 \\
\text { (Norsunitinib) }\end{array}$ & $\begin{array}{l}95 \\
\text { (Sunitinib), } \\
90 \\
\text { (Norsunitinib) }\end{array}$ & $\begin{array}{l}>0.05 \\
\text { (Sunitinib + } \\
\text { Norsunitinib) }\end{array}$ \\
\hline
\end{tabular}


Table 3 Clinical pharmakokinetic profiles of TKI marketed in the EU (Continued)

\begin{tabular}{|c|c|c|c|c|c|c|c|c|}
\hline TKI & DLT & MTD & $\begin{array}{l}\text { Clinical dose } \\
\text { (as recommended } \\
\text { by SmPC) }\end{array}$ & Dosage form & $\begin{array}{l}\text { Human AUC at } \\
\text { the clinical dose } \\
\left(\mathrm{ng}^{*} \mathrm{~h} / \mathrm{ml}\right)\end{array}$ & $\begin{array}{l}\text { In vitro } \mathrm{IC}_{50} \\
\text { values for target } \\
\text { kinase inhibitor } \\
(\mathrm{ng} / \mathrm{ml})\end{array}$ & $\begin{array}{l}\text { Dose-reduction } \\
\text { Liver }\end{array}$ & renal \\
\hline Bosutinib & $\begin{array}{l}\text { Grade } 3 \text { diarrhea, } \\
\text { grade } 3 \text { rash [25] }\end{array}$ & 500 mg, q.d & 500 mg, q.d. & Tablet & $2740 \pm 790$ & $250 \mathrm{nM}[26]$ & & Yes \\
\hline Dasatinib & $\begin{array}{l}\text { Grade } 3 \text { nausea, } \\
\text { grade } 3 \text { fatigue, } \\
\text { grade } 3 \text { rash [27] }\end{array}$ & $>120$ mg b.i.d & $\begin{array}{l}100 \text { mg, q.d. (for } \\
\text { chronic phase), } \\
70 \text { mg, b.i.d. (for } \\
\text { accelerated phase } \\
\text { and blast phase) }\end{array}$ & Tablet & $\begin{array}{l}398.8 \text { (b.i.d. } \\
\text { regimen) }\end{array}$ & 0.0976 & $\begin{array}{l}\text { No, only in } \\
\text { severe liver } \\
\text { impairment }\end{array}$ & No \\
\hline Erlotinib & Diarrhea [28] & 150 mg, q.d. & 150 mg, q.d. & Tablet & 42679 & 0.787 [29] & No & No \\
\hline Gefitinib & $\begin{array}{l}\text { Nausea, diarrhea, } \\
\text { vomiting, rash }\end{array}$ & 700 mg, q.d. & 250 mg, q.d. & Tablet & 7251.5 & $12.1[30]$ & $\begin{array}{l}\text { No, only in } \\
\text { severe liver } \\
\text { impairment }\end{array}$ & No \\
\hline Imatinib & $\begin{array}{l}\text { Nausea, vomiting, } \\
\text { fatigue, diarrhea }\end{array}$ & $\begin{array}{l}>1000 \text { mg, } \\
\text { b.i.d. }\end{array}$ & 400 mg, q.d & Tablet & 33200 & $12.3[31]$ & Yes & No \\
\hline Lapatinib & $\begin{array}{l}\text { Rash, diarrhea, } \\
\text { fatigue }\end{array}$ & 1800 mg, q.d. & 1250 mg, q.d. & Tablet & 33836.5 & $6.02[32]$ & Yes & $\begin{array}{l}\text { No, only in } \\
\text { severe renal } \\
\text { impairment }\end{array}$ \\
\hline Nilotinib & $\begin{array}{l}\text { Liver function } \\
\text { abnormalities, } \\
\text { thrombocytopenia } \\
\text { [33] }\end{array}$ & 600 mg, b.i.d. & $\begin{array}{l}400 \mathrm{mg} \text {, b.i.d. (for } \\
\text { chronic-phase and } \\
\text { accelerated-phase of } \\
\text { chronic myelogenous } \\
\text { leukemia), } 300 \text { mg, b.i.d. } \\
\text { (for newly diagnosed } \\
\text { chronic-phase } \\
\text { myelogenous } \\
\text { leukemia) }\end{array}$ & Capsule & $\begin{array}{l}19000 \text { (b.i.d. } \\
\text { regimen) }\end{array}$ & not available & No & No \\
\hline Pazopanib & $\begin{array}{l}\text { Grade } 3 \text { aspartate } \\
\text { aminotransferase } \\
\text { (AST)/alanine } \\
\text { aminotransferase } \\
\text { (ALT) elevations, } \\
\text { grade } 3 \text { malaise [34] }\end{array}$ & $\begin{array}{l}800 \mathrm{mg} \text {, q.d. } \\
{[35,36]}\end{array}$ & 800 mg, q.d. & Tablet & $\begin{array}{l}650 \pm 500 \\
\mu g^{*} \mathrm{~h} / \mathrm{ml}\end{array}$ & $\begin{array}{l}10,30,47,71,84 \\
\text { or } 74 \mathrm{nM}\end{array}$ & Yes & No \\
\hline Ponatinib & Rash, fatigue & 45 mg, q.d & 45 mg, q.d. & Tablet & $\begin{array}{l}77(50 \%) \text { or } \\
1296(48 \%)\end{array}$ & 0.4 or $2.0 \mathrm{nM}$ & Yes & No \\
\hline Sorafenib & $\begin{array}{l}\text { Hand-foot skin } \\
\text { syndrome } \\
\text { (HFS) [37] }\end{array}$ & 600 mg, b.i.d. & 400 mg, b.i.d. & Tablet & $\begin{array}{l}36690 \text { (b.i.d. } \\
\text { regimen) }\end{array}$ & $7.79[38]$ & No & No \\
\hline Sunitinib & $\begin{array}{l}\text { Grade } 3 \text { fatigue, } \\
\text { grade } 3 \text { hypertension, } \\
\text { grade } 2 \text { bullous skin } \\
\text { toxicity (HFS) [39] }\end{array}$ & 50 mg, q.d. & 50 mg, q.d. & Capsule & 1406 & 0.797 & $\begin{array}{l}\text { No, only in } \\
\text { severe liver } \\
\text { impairment }\end{array}$ & No \\
\hline
\end{tabular}


$95.2 \%$ at 8 years in the literature and thus does not differ statistically significantly from that of the general population [18]. Imatinib is still the most common TKI modality used as a frontline therapy in CML across the world. However, due to the occurrence of Imatinib resistance and intolerance, second generation TKI as Dasatinib, Nilotinib and Bosutinib have been developed. In nonclinical models they are 30 to 300 times more potent than Imatinib and can inhibit most Imatinib-resistant BCR-ABL mutations (EPARs for Imatinib, Dasatinib, and Nilotinib [15]). Comparable with the experience in anti-infective drugs, multidrug-resistant BCR/ABL mutations occur which preclude further use of the approved TKI. For example, patients with T315I mutation respond only on treatment with third generation TKI Ponatinib, which was specifically designed as a treatment option for these populations.

TKI indicated in CML have some side-effects in common as myelosuppression, gastrointestinal complaints, rash, fatigue, headache and peripheral and periorbital edema; however, intensity varies significantly between the different products. Other $\mathrm{AE}$ are peculiar of each drug: Imatinib has been uncommonly associated with severe heart failure, while Nilotinib is associated with QT prolongation, pancreatitis, increased rate of cardiovascular events, and occurrence of peripheral arterial occlusive disease (PAOD). Dasatinib may cause pleural, pericardial and peritoneal effusions; additionally interaction with platelet function is discussed to explain higher rates of gastrointestinal bleeding observed in clinical practice. Bosutinib is associated with significant gastrointestinal toxicity (diarrhea) and hepatotoxicity. Serious AE observed with Ponatinib are an alarming high rate of arterial thrombosis, and cardiovascular events as well as hepatotoxicity.

Differences in the safety profiles of these TKI seem to be at least partially explained by the additional inhibition of other signaling pathways apart BCR-ABL [c-Kit, Src family kinases, PDGFR, and others].

However, it should be kept in mind that TKI treatment of CML has to be administered lifelong and knowledge about potential long-term risks and efficacy, especially for the second generation TKI Dasatinib, Nilotinib and Bosutinib, is still limited. Whether risks associated with Ponatinib treatment can be tolerated is currently under discussion again.

Not only from a regulatory perspective careful attention on recommended risk minimization measures as defined in the product information is at the end essential to avoid treatment complications that may completely jeopardize the sought treatment success.

\section{Orphan drug status of TKI}

The orphan regulation aims at fostering drug development for serious or life-threatening diseases with a prevalence of less than 5 in 10.000 people in the EU. A sponsor may apply for orphan designation any time prior to an application for marketing authorization (usually even before clinical development). The orphan drug status then needs to be confirmed during the marketing authorization procedure. The most important incentive of the regulation is ten year market exclusivity for an orphan medicinal product with respect to similar medicinal products. Neither EMA nor EU member states can authorize a product, which is regarded similar with respect to chemical structure and mode of action and therapeutic indication. Generics, by definition, fulfill all of these criteria.

Imatinib is the paradigm of targeted therapy with its target, the Philadelphia chromosome, occurring in two rare forms of cancer, CML and acute lymphatic leukemia (ALL) which remain rare in spite of recent advances for treatment. Other cancers, e.g. renal cell carcinoma, was recently reported to exceed the prevalence threshold of 5 in 10.000 people so that no further orphan designations are expected.

\section{Orphan similarity and market exclusivity}

In addition to the incentive of the a.m. ten year market exclusivity intended by the European orphan regulation [19] there may be a probably unintended additional incentive. Special circumstances are conceivable under which the market exclusivity granted for orphan products may exclude marketing authorization of a generic product. These special circumstances first occurred when the orphan drug Tasigna ${ }^{\circ}$ (Nilotinib) was assessed as "similar" to Glivec (Imatinib). Glivec ${ }^{\circ}$ was first authorized in the EU in 2003. The Committee for Medicinal Products for Human Use (CHMP) gave a positive opinion on its benefit risk balance, the Committee for Orphan Medicinal Products (COMP) confirmed the significant benefit and so Glivec ${ }^{\circ}$ got the most important incentive for the development of medicines for orphan diseases - the market exclusivity. Under the condition of the European orphan drug regulation no medicinal product "similar" to Glivec $^{\circ}$ would get marketing authorization for ten years unless the similar product had superior efficacy or safety or the MAH of the protected product gives consent to the marketing of the similar product.

Several years after marketing authorization of Glivec $^{\circ}$ was granted, similarity assessment of Tasigna ${ }^{\circ}$ concluded that Tasigna ${ }^{\circ}$ was a similar product to Glivec $^{\circ}$ and the market exclusivity of Glivec ${ }^{\circ}$ would therefore be prohibitive for the authorization of Tasigna ${ }^{\circ}$. In the context of a similarity assessment, three characteristics of a given drug are decisive:

1) The chemical structure (respectively structural similarity to the innovator product)

2) The molecular mechanism of action, and

3) The indication(s). 
In the first step of Tasigna ${ }^{\circ}$ marketing authorization, this was not problematic, because Tasigna ${ }^{\circ}$ was first authorized in second line after first line-therapy with Glivec ${ }^{\circ}$. However, with the extension of indications to first-line treatment of CML, Tasigna ${ }^{\circ}$ was authorized only with the consent of the MAH of Glivec (not surprisingly, as both medicines are products of Novartis). The COMP confirmed a significant benefit and thus Tasigna ${ }^{\circ}$ received its ten own year market exclusivity beginning with the commission decision in 2007.

When data protection and orphan market exclusivity expired for Glivec ${ }^{\oplus}$ generic Imatinib products to the reference product Glivec ${ }^{\circ}$ were submitted. There was, however, the previous regulatory decision that Glivec ${ }^{\circ}$ and Tasigna $^{\circ}$ are similar products - including the assessment of Imatinib and Nilotinib as similar active substances based on their chemical structure and pharmacological mechanism. An authorization of a generic Imatinib product to the reference product Glivec ${ }^{\circ}$ would therefore not be granted if it violated the 10 year market exclusivity of Tasigna ${ }^{\circ}$ which began in 2007.

It is safe to assume that the European orphan legislation was never meant to preclude the authorization of generics after the data protection and the ten years orphan protection of the reference product had expired. And it also seems that this was not a deliberate abuse of a complicated legal and regulatory situation by Novartis but rather unintended. If that had been a wicked, albeit brilliant, marketing-driven strategy, the exact alignment of the indications of Glivec ${ }^{\circ}$ and Tasigna ${ }^{\circ}$ would have effectively prevented any Imatinib generics for many years. As the indications of Tasigna ${ }^{\circ}$ and Glivec ${ }^{\circ}$ overlap for the majority of patients but are not identical, a marketing authorization for Imatinib generics restricted to the indications not granted for Tasigna ${ }^{\circ}$ became possible. This is why the indications of generic Imatinib products are different from the indications of the reference product Glivec ${ }^{\circ}$.

\section{Conclusion}

A decade ago, TKI were introduced into clinical anticancer therapy. At first sight, the molecular mechanism of action appears to comprise only a targeted approach in blocking tyrosine kinases. However, this should not be misleading; numerous closely interconnected signaling pathways are involved and the complexity of TKI molecular mechanism is far from being understood completely. For clinicians, TKI are a worthy new modality of tumor-therapy amending classical cytotoxic regimes. TKI are of substantial benefit in terms of efficacy with a tolerable safety profile. However, long-term safety issues might not be fully elucidated at present and, thus, cannot be finally judged upon. Throughout the next years, many of these substances will run off-patent. Thus, regulatory guidance will be required for instance on whether certain substances like Sunitinib fulfill the criteria of a narrow therapeutic index drug. Apart from that, most TKI are orally administered, thereby raising the question whether BCS-based biowaiver can apply. In addition, design and requirements of BE-studies will be an issue in the EMAinitiative of product specific guidance on anti-cancer-TKI.

\section{Abbreviations}

ADR: Adverse drug reaction; AUC: Area under the curve; ALL: Acute lymphatic leukemia; BCS: Biopharmaceutics Classification System; BE: Bioequivalence; b.i.d.: twice daily; CMA: Conditional marketing; $C_{\text {max }}$ : maximal plasma concentration; $C M L$ : Chronic myeloic leukemia; CHMP: Committee for medicinal products for human use; COMP: Committee for orphan medicinal products; CYP: Cytochrome P450; DLT: Dose limiting toxicity; EMA: European medicines agency; EPAR: European Public Assessment Report; FDA: U.S. Food and Drug Administration; GIST: Gastrointestinal stromal tumor; HFS: Hand foot syndrome; MAA: Marketing authorization applications; MEC: Minimum effective concentrations; MTC: Minimum toxic concentrations; MTD: Maximal tolerated dose; NTID: Narrow therapeutic index drug; NSCLC: Non-small cell lung cancer; PAOD: Peripheral arterial occlusive disease; PK: Pharmakokinetic; pNET: pancreatic neuroendocrine tumors; q.d.: every day; RTK: Receptor tyrosine kinase; STS: Soft tissue sarcoma; TKI: Tyrosine kinase inhibitor tmax, time after administration when Cmax is reached.

\section{Competing interests}

The authors declare that they have no competing interests.

\section{Authors' contributions}

All authors filed the manuscript, NE and LR performed a systematic search on clinical PK-parameter. All authors read and approved the final manuscript.

\section{Disclaimer}

The opinions mentioned throughout the following article are personal views of the authors and do not reflect an official position of the Federal Institute of Drugs and Medical Devices or an EMA-committee or working party, respectively.

\section{Funding}

The support of Andreas Duda is gratefully acknowledged. This systematic review article was supported by intramural funding of the Federal Institute for Drugs and Medical Devices (BfArM).

Received: 27 January 2014 Accepted: 3 February 2014

Published: 7 February 2014

\section{References}

1. Siegel R, Naishadham D, Jemal A: Cancer statistics, 2013. CA Cancer J Clin 2013, 63:11-30.

2. Laurie SA, Goss GD: Role of epidermal growth factor receptor inhibitors in epidermal growth factor receptor wild-type non-small-cell lung cancer. J Clin Oncol 2013, 31:1061-1069.

3. Hynes NE, Lane HA: ERBB receptors and cancer: the complexity of targeted inhibitors. Nat Rev Cancer 2005, 5:341-354.

4. Koberle B, Tomicic MT, Usanova S, Kaina B: Cisplatin resistance: preclinical findings and clinical implications. Biochim Biophys Acta 1806, 2010:172-182

5. Eckstein N, Servan K, Girard L, Cai D, Von JG, Jaehde U, Kassack MU, Gazdar $A F$, Minna JD, Royer HD: Epidermal growth factor receptor pathway analysis identifies amphiregulin as a key factor for cisplatin resistance of human breast cancer cells. J Biol Chem 2008, 283:739-750.

6. Eckstein N: Platinum resistance in breast and ovarian cancer cell lines. J Exp Clin Cancer Res 2011, 30:91.

7. Stommel JM, Kimmelman $\mathrm{AC}$, Ying $\mathrm{H}$, Nabioullin $\mathrm{R}$, Ponugoti $\mathrm{AH}$, Wiedemeyer R, Stegh AH, Bradner JE, Ligon KL, Brennan C, et al: Coactivation of receptor tyrosine kinases affects the response of tumor cells to targeted therapies. Science 2007, 318:287-290. 
8. Engelman JA, Luo J, Cantley LC: The evolution of phosphatidylinositol 3-kinases as regulators of growth and metabolism. Nat Rev Genet 2006, 7:606-619.

9. Murray S, Karavasilis V, Bobos M, Razis E, Papadopoulos S, Christodoulou C, Kosmidis P, Fountzilas G: Molecular predictors of response to tyrosine kinase inhibitors in patients with non-small-cell lung cancer. J Exp Clin Cancer Res 2012, 31:77.

10. Wang F, Wang S, Wang Z, Duan J, An T, Zhao J, Bai H, Wang J: Phosphorylated EGFR expression may predict outcome of EGFR-TKIs therapy for the advanced NSCLC patients with wild-type EGFR. J Exp Clin Cancer Res 2012, 31:65.

11. Mattoon DR, Lamothe B, Lax I, Schlessinger J: The docking protein Gab1 is the primary mediator of EGF-stimulated activation of the PI-3 K/Akt cell survival pathway. BMC Biol 2004, 2:24.

12. Kiyatkin A, Aksamitiene E, Markevich NI, Borisov NM, Hoek JB, Kholodenko BN: Scaffolding protein Grb2-associated binder 1 sustains epidermal growth factor-induced mitogenic and survival signaling by multiple positive feedback loops. J Biol Chem 2006, 281:19925-19938.

13. Ashkenazi A, Herbst RS: To kill a tumor cell: the potential of proapoptotic receptor agonists. J Clin Invest 2008, 118:1979-1990.

14. European Medicines Agency: Guideline on the Investigation of Bioequivalence. London; 2010. CPMP/EWP/QWP/1401/98 Rev. 1/ Corr**.

15. European medicins agency. http://www.ema.europa.eu/ema/.

16. HumanMRIndex. http://mri.medagencies.org/Human/.

17. Quintas-Cardama A, Cortes JE: Chronic myeloid leukemia: diagnosis and treatment. Mayo Clin Proc 2006, 81:973-988.

18. Gambacorti-Passerini C, Antolini L, Mahon FX, Guilhot F, Deininger M, Fava C, Nagler A, Della Casa CM, Morra E, Abruzzese E, et al: Multicenter independent assessment of outcomes in chronic myeloid leukemia patients treated with imatinib. J Natl Cancer Inst 2011, 103:553-561.

19. Regulation (EC) No 141/2000 of the European Parliament and of the Council on Orphan Medicinal Products. 2013. http://eur-lex.europa.eu/.

20. Golas JM, Lucas J, Etienne C, Golas J, Discafani C, Sridharan L, Boghaert E, Arndt K, Ye F, Boschelli DH, et al: SKI-606, a Src/Abl inhibitor with in vivo activity in colon tumor xenograft models. Cancer Res 2005, 65:5358-5364.

21. Abbas R, Hug BA, Leister C, Gaaloul ME, Chalon S, Sonnichsen D: A phase I ascending single-dose study of the safety, tolerability, and pharmacokinetics of bosutinib (SKI-606) in healthy adult subjects. Cancer Chemother Pharmacol 2012, 69:221-227.

22. Birch M, Morgan PE, Handley S, Ho A, Ireland R, Flanagan RJ: Simple methodology for the therapeutic drug monitoring of the tyrosine kinase inhibitors dasatinib and imatinib. Biomed Chromatogr 2013, 27:335-342.

23. Burris HA III, Taylor CW, Jones SF, Koch KM, Versola MJ, Arya N, Fleming RA, Smith DA, Pandite L, Spector $N$, et al: A phase I and pharmacokinetic study of oral lapatinib administered once or twice daily in patients with solid malignancies. Clin Cancer Res 2009, 15:6702-6708.

24. Giles FJ, Yin OQ, Sallas WM, le Coutre PD, Woodman RC, Ottmann OG, Baccarani M, Kantarjian HM: Nilotinib population pharmacokinetics and exposure-response analysis in patients with imatinib-resistant or -intolerant chronic myeloid leukemia. Eur J Clin Pharmacol 2013, 69:813-823.

25. Daud Al, Krishnamurthi SS, Saleh MN, Gitlitz BJ, Borad MJ, Gold PJ, Chiorean EG, Springett GM, Abbas R, Agarwal S, et al: Phase I study of bosutinib, a src/abl tyrosine kinase inhibitor, administered to patients with advanced solid tumors. Clin Cancer Res 2012, 18:1092-1100.

26. Vultur A, Buettner R, Kowolik C, Liang W, Smith D, Boschelli F, Jove R: SKI-606 (bosutinib), a novel Src kinase inhibitor, suppresses migration and invasion of human breast cancer cells. Mol Cancer Ther 2008, 7:1185-1194.

27. Demetri GD, Lo RP, MacPherson IR, Wang D, Morgan JA, Brunton VG, Paliwal $P$, Agrawal S, Voi M, Evans TR: Phase I dose-escalation and pharmacokinetic study of dasatinib in patients with advanced solid tumors. Clin Cancer Res 2009, 15:6232-6240.

28. Bonomi P: Erlotinib: a new therapeutic approach for non-small cell lung cancer. Expert Opin Investig Drugs 2003, 12:1395-1401.

29. Moyer JD, Barbacci EG, Iwata KK, Arnold L, Boman B, Cunningham A, DiOrio C, Doty J, Morin MJ, Moyer MP, et al: Induction of apoptosis and cell cycle arrest by CP-358,774, an inhibitor of epidermal growth factor receptor tyrosine kinase. Cancer Res 1997, 57:4838-4848.
30. Wakeling AE, Guy SP, Woodburn JR, Ashton SE, Curry BJ, Barker AJ, Gibson KH: ZD1839 (Iressa): an orally active inhibitor of epidermal growth factor signaling with potential for cancer therapy. Cancer Res 2002, 62:5749-5754.

31. Druker BJ, Tamura S, Buchdunger E, Ohno S, Segal GM, Fanning S, Zimmermann J, Lydon NB: Effects of a selective inhibitor of the Abl tyrosine kinase on the growth of Bcr-Abl positive cells. Nat Med 1996, 2:561-566

32. Rusnak DW, Lackey K, Affleck K, Wood ER, Alligood KJ, Rhodes N, Keith BR, Murray DM, Knight WB, Mullin RJ, et al: The effects of the novel, reversible epidermal growth factor receptor/ErbB-2 tyrosine kinase inhibitor, GW2016, on the growth of human normal and tumor-derived cell lines in vitro and in vivo. Mol Cancer Ther 2001, 1:85-94.

33. Kantarjian H, Le CP, Cortes J, Pinilla-lbarz J, Nagler A, Hochhaus A, Kimura S, Ottmann O: Phase 1 study of INNO-406, a dual AbI/Lyn kinase inhibitor, in Philadelphia chromosome-positive leukemias after imatinib resistance or intolerance. Cancer 2010, 116:2665-2672.

34. Yau T, Chen PJ, Chan P, Curtis CM, Murphy PS, Suttle AB, Gauvin J, Hodge JP, Dar MM, Poon RT: Phase I dose-finding study of pazopanib in hepatocellular carcinoma: evaluation of early efficacy, pharmacokinetics, and pharmacodynamics. Clin Cancer Res 2011, 17:6914-6923.

35. Shibata SI, Chung V, Synold TW, Longmate JA, Suttle AB, Ottesen LH, Lenz HJ, Kummar S, Harvey RD, Hamilton AL, et al: Phase I study of pazopanib in patients with advanced solid tumors and hepatic dysfunction: a national cancer institute organ dysfunction working group study. Clin Cancer Res 2013, 19:3631-3639.

36. Infante JR, Novello S, Ma WW, Dy GK, Bendell JC, Huff A, Wang Q, Suttle AB, Allen $R, X u C F$, et al: Phase Ib trial of the oral angiogenesis inhibitor pazopanib administered concurrently with pemetrexed in patients with advanced solid tumors. Invest New Drugs 2013, 31:927-936.

37. Moore M, Hirte HW, Siu L, Oza A, Hotte SJ, Petrenciuc O, Cihon F, Lathia C, Schwartz B: Phase I study to determine the safety and pharmacokinetics of the novel Raf kinase and VEGFR inhibitor BAY 43-9006, administered for 28 days on/7 days off in patients with advanced, refractory solid tumors. Ann Oncol 2005, 16:1688-1694.

38. Wilhelm SM, Carter C, Tang L, Wilkie D, McNabola A, Rong H, Chen C, Zhang $X$, Vincent $P$, McHugh M, et al: BAY 43-9006 exhibits broad spectrum oral antitumor activity and targets the RAF/MEK/ERK pathway and receptor tyrosine kinases involved in tumor progression and angiogenesis. Cancer Res 2004, 64:7099-7109.

39. Faivre S, Delbaldo C, Vera K, Robert C, Lozahic S, Lassau N, Bello C, Deprimo S, Brega N, Massimini G, et al: Safety, pharmacokinetic, and antitumor activity of SU11248, a novel oral multitarget tyrosine kinase inhibitor, in patients with cancer. J Clin Oncol 2006, 24:25-35.

doi:10.1186/1756-9966-33-15

Cite this article as: Eckstein et al: Clinical pharmacology of tyrosine kinase inhibitors becoming generic drugs: the regulatory perspective. Journal of Experimental \& Clinical Cancer Research 2014 33:15.

\section{Submit your next manuscript to BioMed Central and take full advantage of:}

- Convenient online submission

- Thorough peer review

- No space constraints or color figure charges

- Immediate publication on acceptance

- Inclusion in PubMed, CAS, Scopus and Google Scholar

- Research which is freely available for redistribution 